ROBERT MUHA, Ph.D. ${ }^{1}$

E-mail: robert.muha@fpp.uni-lj.si

(Corresponding author)

SEBASTJAN ŠKERLIČ, Ph.D. ${ }^{1}$

E-mail: sebastjan.skerlic@fpp.uni-lj.si

VANJA ERČULJ, M.Sc. ${ }^{2}$

E-mail: vanja.erculj@fvv.uni-mb.si

${ }^{1}$ University of Ljubljana

Faculty of Maritime Studies and Transport

Pot pomorščakov 4, 6320 Portorož, Slovenia

${ }^{2}$ University of Maribor

Faculty of Criminal Justice and Security

Kotnikova ulica 8, 1000 Ljubljana, Slovenia
Transport Logistics Original Scientific Paper Submitted: 11 Mar. 2019 Accepted: 2 Oct. 2019

\title{
THE IMPORTANCE OF RISK MANAGEMENT FOR THE INTRODUCTION OF MODERN WAREHOUSE TECHNOLOGIES
}

\begin{abstract}
The purpose of the study is to determine whether the presence of risk management in a warehouse requires the implementation of modern warehouse technology. On the basis of the literature analysis, it was possible to determine that there is a correlation between the presence of the highest level of risk management and the use of modern warehouse technology in individual warehousing processes. For this purpose, a statistical analysis was carried out on a sample of companies operating in the Slovenian automotive industry. The results did not reveal a tangible correlation between the presence of risk management with the use of individual modern warehouse technology, the motivation for its use and errors in its use. The results of the study therefore, highlight the problems that are present in the warehousing system of the Slovenian companies in the automotive industry, which are related to substandard technological equipment in the warehouses and to the discrepancy between the level of manufacturing automation and the level of warehousing automation. The results are important for the Slovenian automotive industry in terms of the implementation of modern warehouse technology in the high-tech automotive industry.
\end{abstract}

\section{KEY WORDS}

warehousing; risk management; warehousing reliability; warehouse technology; methods; case study;

\section{INTRODUCTION}

Ensuring the reliability of the warehousing system is one of the basic functions of a company logistics management. Warehousing reliability depends on the availability for supply (unloading, receiving and putting away) and for dispatching goods (retrieving, replenishing, picking, sorting, consolidation, loading). The quality of logistics services provided by the warehouse can be considered sufficient if the number and structure of qualitative errors is low, if services are provided on time, and if the customer orders can be sped up or cancelled without any potential errors arising [1].

The warehousing reliability is closely linked to the use of modern technology, which is designed to increase productivity and quality of work. Employing modern warehouse technology ensures a more rational use of warehouse space, reduced use of energy and labour, improved control of warehousing processes, and fewer manual handling operations, which results in lower operating costs and fewer work-related accidents [2-4]. The reliability of warehouse processes has increased significantly with the introduction of modern technology, as its use eliminates the main risks that are inherent to the operation of a warehouse. Richards [5] identifies two main categories of modern warehouse technology. The first is the storage and handling equipment, which includes Automated Guided Vehicles with a navigation system - AGV, and Automated Storage and Retrieval Systems - AS/RS. The latter category refers to modern order-picking solutions, such as Warehousing Management System (WMS), Radio Frequency Identification Technology (RFID), Voice Picking Technology (PbV) and Light Picking Technology $(\mathrm{PbL})$. 
However, the question remains: why is this technology not more commonly used? Since we are living in the age of the fourth industrial revolution, also referred to as Industry 4.0, this question is a fundamental driving force of the current research, which explores the issue of employing modern technological solutions. Tsarouchi et al. [6] found in their study that during the period from 1980 to 1989 , only 67 studies on this subject were published, while the number rose to 3,153 in the period from 2010 to 2015 .

Scientific studies on the subject are mainly studies focusing on the interaction between the warehouse operator and automation, where the main reason that prevents the implementation of more modern technological solutions is associated with mistrust and lack of knowledge on the part of the operators [7-10]. Designing, building, managing, maintaining and controlling various technologies and systems that are particularly characteristic of the modern warehouse process, requires greater focus on risk management, whose main task is to establish a safety culture in the company. Therefore, it is particularly important to highlight a culture of reporting errors and risks within the warehouse, which in this respect represents the highest level of development of risk management in companies [11]. The carriers and users of this kind of risk management approach are warehouse operators who directly interact with modern technology. It is precisely because of this that risk management and the associated error reporting culture are all the more important for establishing and using the modern warehouse technology. This is also a condition that must be fulfilled before any issues arising due to mistrust and lack of knowledge on the part of warehouse operators can be solved.

Since the studies are strongly oriented towards the operator-automation interaction, there is a noticeable research gap in the available literature on the subject, as apparently there are no studies focusing on the role of risk management in the use of modern warehouse technology. The use of modern technology in warehousing is a fundamental competitive advantage for companies. Thus, the objective of the study is to determine whether the development of risk management is heading in the direction of introducing modern technological solutions in an efficient manner. To this end, a survey was carried out on a sample of 24 Slovenian companies that operate in the international automotive industry and represent an important source of information between industrial practice and academic research. So far, no research has been carried out to specifically illustrate the impact of risk management on introducing modern technological solutions into warehousing. The study thus upgrades the existing knowledge and provides companies in the Slovenian automotive industry with the guiding principles for providing reliable and efficient warehousing processes. As the automotive industry is a generator of technological progress on the global level, the results of the research can also affect other industrial sectors in the region.

The paper is structured as follows: the second Section provides a literature overview, highlighting the connection between risk management and modern technology. The paper continues with the analysis and discussion of the results. This part presents a contribution to the impact of risk management on the implementation of modern warehouse technology. The final Section outlines the limitations of the study and provides suggestions for further research.

\section{LITERATURE REVIEW}

The specific features of warehousing in the automotive industry is a result of the complexity of the industry operation, as modern cars contain 15,000 separate parts supplied by about 200 to 400 different suppliers, who, in turn, have their own sub-suppliers [12]. Managing such quantities of different products requires a coordinated effort by all warehouse processes, both on the part of car manufacturers and within the supply chain [13]. Over time, the field of warehouse management has evolved to such a level that it has become a reference point for other industry sectors in terms of managing logistic processes. In the automotive industry, it is absolutely essential that warehouse processes such as receiving, pre-packing, put-away, storage, processing customer orders, packaging, sorting and shipping are reliable. Warehousing is an area where errors occur quite often, which makes the implementation of risk management a fundamental tool for ensuring the safety and reliability of warehouse processes. With the introduction of modern technologies, warehousing has gained new possibilities for development. However, according to various authors, the use of modern technology has led to a reduction in the physical movement of goods by operators, which has, in turn, led to a reduction in the number of such errors. On the other hand, the use of modern 
warehouse technology has generated a different type of error that was previously unknown $[11,14$, 15]. For the purpose of understanding the connection between risk management and modern technology, both areas will be presented in this part of the literature review, based on which a scientific question will be formulated.

\subsection{Use of risk management in a warehouse}

Effective risk management carries the benefits of improved warehouse efficiency and financial performance and increases the company competitive advantage. It enables the warehouse managers to efficiently manage all types of risks and to recover quickly in case of any disruptions. Since risks can have a significant impact on the performance of a business in the short and long term, companies from all industry sectors can suffer losses, unless they treat this subject as a priority and in a systemic manner. Thus, risk management requires continuous attention when planning logistics operations [16].

As the warehousing process is part of a company supply chain, the overall performance of the risk management system relates to the concepts of Supply Chain Risk Management (SCRM). SCRM is focused on managing risks along the supply chain through coordination and collaboration between partner companies for the purpose of generating profitability and continuity $[17,18]$. The relevance of SCRM is presented through the work of Ho et al. [19], who have reviewed 224 international journal articles on SCRM published between 2003 and 2013. Among these articles, 208 applied quantitative or qualitative research methods to deal with the SCRM processes, including risk identification, risk assessment, risk mitigation, and risk monitoring. The authors identified five common risk factors that arise between different types of supply chains, including macro risk, demand risk, manufacturing risk, supply risk and infrastructural risk (information, transport, and financial risk). All these risk factors also have an impact on the warehouse process. Due to the complex network of companies within the supply chain, risk management is also defined by ISO 31000, where this process is divided into three phases: (i) risk identification, (ii) risk analysis, and (iii) risk evaluation, the aim of which is to reduce, monitor and control the probability and impact of undesirable events [20].
However, the development of systems for ensuring the reliability of warehousing processes began in the mid-1950s in Japan. The 5S methodology was first implemented in manufacturing under the Toyota Production System [21]. The main benefits of the $5 \mathrm{~S}$ method are: a cleaner, tidier and more orderly work environment, safer working conditions, reduction of non-value-adding activities, better quality and higher productivity, fewer defects and better availability of equipment, as well as fewer equipment and tools needed [22]. A review in the scientific literature shows that the $5 \mathrm{~S}$ method is still being used in all the developed industries and is also addressed by the current research.

An important contribution to the development of methodological approaches to ensuring warehousing reliability was made by the UK Health and Safety Executive [23], who have published a book in conjunction with the Warehousing Health and Safety Forum - a joint committee with representation from trade unions, trade associations and employer bodies. It covers many special attention topics, including manual handling and musculoskeletal disorders; slips and trips; workplace transport; and falls from the height. It also contains instructions on handling other hazards in warehouses, such as storage systems, mechanical handling, and electrical safety. The HSE propose a five-step risk assessment method to be used in a warehouse: Step 1 - Identify the hazard, Step 2 - Decide who may be harmed, and how, Step 3 - Assess the risks and take action, Step 4 - Make a record of the findings, and Step 5 Review the risk assessment, which may have to be updated as needed.

Various authors also explored the ways for improving the reliability of the warehousing process by introducing different methodological approaches to preventing errors in warehouse operations. Not many methods exist, as risk management in warehousing is often dealt with within the company supply chain through SCRM implementation. Nonetheless, the methods that do exist have a significant impact on improving the reliability of warehousing within a company. One of the most commonly used and widely accepted reliability method in the industry practice is Fault Tree Analysis (FTA), developed by Yan et al. [24]. This method allows for system failure to be expressed through the interaction of its components. Moreover, with the aid of FTA, the probability of system or mission failure can be computed via Boolean logic calculations. This method 
has been adopted to evaluate the subsystem level failures for the AGV system (Automated Guided Vehicles System). The proposed method is an effective approach for conducting AGV system mission reliability assessment, providing the capability to make informed decisions regarding the acceptability of AGV mission performance.

Choy et al. [25] proposed a model for analysing the reliability of the warehousing system, which focuses on resource capability, under given combinations of storage, routing, batching and zoning process policies. Based on the analysis, an assessment of the effect of different operational combinations on the reliability of the warehouse is then performed. To better reflect the actual order picking operations in a warehouse, a simulation model is provided, based on the operating scenarios of a logistics company in Hong Kong.

Lam et al. [16] developed Knowledge-based Logistics Operations Planning (K-LOPS), which provides support to the decision-making process, especially in terms of planning and controlling the warehousing operations. K-LOPS uses Radio Frequency Identification Technology (RFID) and Artificial Intelligence Technology, i.e. the Analytical Hierarchy Process (AHP) and Case-based Reasoning (CBR) to collect real-time warehouse data and relevant logistical data to support decision-making in the event of operational problems. The use of the proposed system eliminates the risks associated with the process of warehouse operations planning. Ryu et al. [26] propose a model that focuses on the interaction between operator and machine. On this basis, they modelled when the operator can intervene in the automated system through their actions. The model's advantage lies in the fact that it is able to model more efficiently the probability of human behaviour in decision making, based on acquiring knowledge and on the choice of actions based on past experience. This kind of approach is particularly important in the warehouse process of a company, where there is often a dilemma about when it is appropriate for the warehouse operator to intervene in the operation of an automated warehousing system. A similar approach was developed by Cochran et al. [27], which proposes a systematic approach to modelling the operator - machine interaction. It focuses on the process of controlling the operation of automated systems and their efficient employment. The proposed model can be used to design warehousing systems at various levels of the company, especially in areas where operators work with semi-automated processes.

Caputo et al. [28] developed a model to assess errors probability and errors correction costs in kit preparation and delivery processes feeding parts to assembly lines. Error trees and event trees are adopted to keep track of unwanted events and error correction opportunities during the entire logistic process, starting from material picking in the warehouse to kit delivery at workstations and parts assembly. A numerical example is presented, illustrating the use of the method and assessing the contribution of each potential error to the total cost of quality in kitting systems. The method is aimed at quantifying the economic consequences of errors in the parts feeding the logistic process, and identifying the major error sources. Jacyna-Gołda and Lewczuk [1] examined the issues related to the assessment of warehouse performance, quality problems, and solutions designed to increase the quality of work. Technical and organizational redundancy was proposed as a primary factor that increases the reliability of warehousing operations in the supply chain, thereby improving the quality of services. An approach to assessing warehousing reliability is proposed, based on the technological and organizational redundancy, related to material flow pile-ups. The approach is based on the OTIFEF index as the basis for assessing the reliability of the warehousing process.

\subsection{Connecting risk management using modern warehouse technology}

The study published by the UK Health and Safety Executive [23] identifies the main causes of accidents in the warehouses, which are slips and trips, manual handling, falls from height, being hit by moving or falling objects, being hit by a moving vehicle, being hit by something fixed or stationary, and other kinds of accidents. Most accidents are due to slips and trips (26\%), manual handling $(18 \%)$ and falls from height (16\%). With the use of Automated Guided Vehicles with a navigation system - AGV and Automated Storage and Retrieval Systems - AS/RS, it is possible to reduce the potential risks of injuries and errors in the warehouse, on account of the reduction in manual work. This type of modern technology eliminates the potential risks 
observed during warehouse operations that are associated with receiving, put-away, storage, packing and loading.

For intelligent transportation and distribution of materials in warehouses and/or manufacturing facilities, there has been an increase in the use of Automated Guided Vehicles (AGVs) in recent years. Such vehicles travel along predefined routes to deliver various tasks without the supervision of an on-board operator [24]. The most state-of-theart warehouse equipment also includes an automated storage and retrieval system (AS/RS), which is the main category of equipment for material handling. There are two major types: unit load AS/ RS and mini-load AS/RS. AS/RS in most cases is comprised of conveyors, Storage Racks (SR) and Automated Storage/Retrieval (S/R) machines [29]. Conventional AS/RS with a single route consists of a rack structure, a storage/retrieval crane with a single load handling device (shuttle), which serves the rack locations, the connection to other systems in the warehouse via input/output conveyors and the control system which schedules AS/RS operations. The increasing number of AS/RS applications in warehousing has led to various changes to the conventional AS/RS. The multi-shuttle AS/RS, containing a number of load-handling devices on a single crane, demonstrated significant improvement in the system performance compared to single-shuttle systems [30].

However, in terms of the costs resulting from individual warehousing operations, Richards [31] singles out the order-picking process, which accounts for $35 \%$ of the overall warehouse costs structure. This warehousing process is therefore, the main focus of several authors $[14,32,33]$, as it has the greatest impact on the customer service. Errors in the order-picking process cause an increase in costs, because they require goods to be received a second time, added labour costs due to manipulation and checking of goods upon return, acceptance of substitute goods, repackaging, re-delivery, administrative costs and the possibility of write-off of stocks if the goods are returned after the acceptable delivery period or damaged in transit [2]. These risks for errors in the order-picking process can be avoided by implementing modern technological solutions, such as Warehousing Management System (WMS), Radio Frequency Identification Technology (RFID), Voice Picking Technology (PbV) and Light Picking Technology (PbL).
The use of modern technological solutions in the warehousing process starts with the implementation of WMS, which has a significant impact on the optimization of warehousing processes from inbound logistics, accepting products from manufacturing, internal warehouse processes, inventory, planning and management of warehouse resources, outbound logistics to optimal stock management within the available warehouse capacities [34]. RFID is one of the new technologies that enable automatic identification and data capture in real time. It is closely connected to the use of WMS. RFID allows the transfer of data between the transmitter and the receiver without physical contact between them. RFID tags are made of an integrated circuit that stores and processes data and is also used to modulate/demodulate signals. This technology has been adopted in various industries to reduce the inventory losses, increase the efficiency of processes and improve information accuracy [16].

The Pick-by-voice system is complementary with the existing WMS system or with ERP (Enterprise Resource Planning) in the form of added value. The information is transmitted from a host over a wireless network and sent to a control unit worn around the operator's waist. The control unit receives radio waves (RF) and converts data into audio signals. The received assignments are generated in audible commands to the operator. After receiving a command, the operator gives a vocal response to the control unit. Using simple communication, the operator confirms the actions taken, and the pick-by-voice system responds with the next assignment. The response is translated into data and the host system is updated [35]. Marchet et al. [36] highlighted the following advantages of $\mathrm{PbV}$ technology: accuracy of inventory and product picking, increased productivity of warehouse operators, lower operating costs, natural communication and increased safety at work.

Light Picking Technology (PbL) or Light-byvoice system is also complementary with the existing WMS system, which guides the warehouse operator using light signals or lights to a particular location. An illuminated lamp signals the location of the goods that are part of the order. In addition to the lights, a button is also implemented, which is used by the employee to confirm that the picking procedure was completed at this location, as well as an LCD screen, which provides the employee with information about the quantity. Once the procedure 
is completed, the employee can focus on the next item where the light is on. The positive effects of this technology are reflected in improved performance and accuracy of warehouse employees [5].

Because of the introduction of these modern technological solutions, the warehouse process changes and a new type of risk emerges; mostly due to the processing of large amounts of data in the same warehouse process, which make up the largest share of warehousing costs incurred by a company - the order picking process. The warehouse operators thus interact with information more than with the physical movement of goods [14]. From this point of view, there is a fundamental connection between risk management and the introduction of modern technology in warehousing. Designing, building, managing, maintaining, and controlling various technologies and management systems that are particularly characteristic of the modern warehouse process, requires greater focus on risk management, whose main task is to establish a safety culture in the company. This is also the basic condition for any errors and risks in the work process to be dealt with strategically, with the goal of ensuring the long-term stability of the company.

Many authors are aware of this [11, 15, 37], and have developed various solutions. Hollnagel [37] emphasized the importance of cooperation among employees, with the purpose of generating ideas and transferring mutual knowledge into the business process of the company. Dekker [15] singled out the factors that constitute a strong safety culture: awareness of the importance of safety and cooperation of top management, commitment and responsibility of employees to ensure safety, safety promotion structures, and reporting systems (efficient flow of information related to safety). Reason's [11] contribution is of particular relevance, as he highlighted the importance of creating a culture of error and risk reporting, which, in this respect, is the highest level of managerial risk management in companies. It represents the ideal of how business processes should work, since the growth and stability of the organization is a common goal to all employees in the company.

Risk management and the associated error reporting culture can have a significant effect on the implementation and use of modern warehouse technology. There are many studies focusing on the interaction between the warehouse operator and automation, where the main reason that prevents the implementation of more modern technological solutions is associated with mistrust and lack of knowledge [7-10]. By establishing the highest level of risk management, it is possible to overcome the potential issues arising from the adoption (or use) of modern technology in warehousing, through an error reporting culture. In can be concluded that by establishing a high level of risk management, the warehouse operators will effectively participate in the design, creation, management, maintenance and control of modern technological solutions.

Since studies are strongly oriented towards the operator - automation interaction, there is a noticeable research gap in the available literature on the subject, as apparently there are no studies focusing on the role of risk management in the increased use of modern warehouse technology. On this basis, the following scientific question is addressed:

Does the presence of risk management in a warehouse affect the implementation of modern warehouse technology? Without a clear answer to this scientific question, any researchers' initiatives connected with studying the attitude towards the introduction of modern technological solutions in warehousing may be less effective. In the age of Industry 4.0 , this is a field that needs to be explored, as only responsive, cost-competitive and flexible companies will be able to succeed. Successful automation of warehousing plays a key role in this, but only if the basic levers affecting this process are thoroughly investigated.

The scientific question will therefore be verified by the following hypotheses:

H1: The presence of risk management is conditional upon an increased use of modern warehouse technology.

$\mathrm{H} 2$ : The presence of risk management influences the motivation of the company management to introduce modern warehouse technology.

H3: The presence of risk management affects the frequency of errors in the use of modern warehouse technology.

The hypotheses have been developed in order to examine the three factors in which risk management influences the use of modern warehouse technology: the type of modern technology used (H1), the motivation for use (H2) and the errors arising during use (H3). The formulation of the first hypothesis (H1) is based on the assumption that the presence of risk management in the warehouse affects the use of modern technology. The fundamental guideline of 
risk management is to strengthen the safety culture, and the implementation of modern technology can have a significant effect on the reduction of workplace accidents and on the strengthening of other security elements in the warehouse. The second hypothesis (H2) focuses on the reasons or the motivation of the company management to use a modern warehouse technology. Since the company management is a generator of improvements from the point of view of safety and technology, the hypothesis is focused on determining the impact of the presence of motivation for the implementation of modern technology in the warehouse, where risk management is present. The third hypothesis (H3) aims to determine whether the presence of risk management has an effect on the frequency of errors in the use of modern warehouse technology. The use of modern technology reduces the number of manual handling operations and related workplace accidents, and therefore, has a significant impact on risk management in the warehouse. However, it is not clear how it affects other types of errors, as, due to the use of modern technology, warehouse operators interact more with information than with the physical movement of goods.

\section{METHODOLOGY}

The study is part of a larger-scale research, created in cooperation with the Slovenian Automotive Cluster (ACS), which is an economic interest association of the Slovenian suppliers to the automotive industry and motor vehicle manufacturers. The cluster was created in order to strengthen the companies competitive ability and to increase the added value. The ACS is the central communication point of the automotive cluster, supported by infrastructure. The ACS supports its members who wish to enter the global motor vehicle industry market with joint promotions and with highly technologically complex products. To this end, it increases the efficiency of members' operations through research and connecting with professional development and scientific institutions at home and abroad. The ACS network connects the automotive component manufacturers operating in the developed metal, electrical and electronic, mechanical, metallurgical, rubber, chemical and textile industries. The network also includes the transport industry and providers of research, development, production and other services who develop and produce products and provide services for the automotive industry. The
Slovenian automotive and automotive supplier industry is traditionally export-intensive and operates according to standards, recognized in the EU and global market, such as QS 9000, VDA, EAQF and ISO TS 16949 [38].

The research was divided into two parts. The first part resulted in a study, which had the objective of determining the advantages of using modern technology by suppliers in the Slovenian automotive industry. The aim of the second, current part of the research, is to determine whether the development of risk management is heading in the direction of introducing modern technological solutions into warehousing in an efficient manner. Via ACS, 35 suppliers of the international automotive industry were invited to participate in the survey, out of which 24 accepted the invitation. For this purpose, a questionnaire was prepared, which was filled out by the warehouse or logistics managers. First, the management of each company that provided the contact information of the persons in charge of completing the questionnaire was contacted via ACS. After the online questionnaire was submitted, the contact persons were contacted once again by telephone to eliminate any ambiguities that might have arisen when answering the questions. The first part of the questionnaire consisted of questions of general nature about the size of the company, its revenues by years and the educational structure of the employees involved in the warehouse operations. The second part of the questionnaire consisted of questions related to the management of all warehouse processes in the companies. For the purposes of analysis, the respondents were asked about the presence of a risk management system in the warehouse, the reasons for the implementation of a risk management system in the warehouse, or lack thereof, the frequency of use of each individual warehouse technology, the reasons that led management to introduce modern warehouse technology in the company, and the frequency of errors in the use of a particular modern warehouse technology.

Modern warehouse technology is categorized according to Richards [4]. The first category is storage and handling equipment, which includes Automated Guided Vehicles with a navigation system (AGV), and Automated Storage and Retrieval Systems (AS/RS). The second category, modern order-picking solutions, includes Radio Frequency Identification Technology (RFID), Warehousing Management System (WMS), Voice Picking 
Technology $(\mathrm{PbV})$ and Light Picking Technology $(\mathrm{PbL})$. The validity of the measurement of the reasons for employing the technology in the work process was verified by the factor analysis, while reliability was assessed using the Cronbach alpha coefficient. The differences in categorical variables between the companies that have a risk management system and others were tested by the likelihood ratio test and in continuous variables by an independent samples t-test. The hypotheses were tested at the level of significance $\alpha=0.05$.

\section{RESULTS}

The sample included $2(8.3 \%)$ small, $10(41.7 \%)$ medium and $12(50 \%)$ large companies. Three quarters of the companies have a risk management system in the warehousing process. The most common reasons for implementing a warehouse risk management system (Table 1) is to improve the quality of warehousing processes $(10 ; 55.6 \%)$, reduce costs and achieve greater control over work processes (both 3, 16.7\%). The most common reason given by companies for not using a warehouse risk management system is that warehousing is a less important process for them, followed by a lack of knowledge and experience and by the high costs associated with the introduction of such a system.

The results of testing the first hypothesis (H1) by likelihood ratio test are shown in Table 2. The goal is to determine whether the presence of risk management is conditional upon an increased use of modern warehouse technology. Table 2 shows the number and share of companies that often or very often use a particular warehouse technology by group of companies according to the use of a risk management system. The use of storage and handling equipment (Automated Guided Vehicles with navigation system - AGV, Automated Storage and Retrieval System - AS/RS) and order-picking

Table 1 - Reasons for implementing a risk management system in the warehouse

\begin{tabular}{||l|c||}
\hline We have a risk management system in the warehouse & $18(75 \%)$ \\
\hline Reasons: & $3(16.7 \%)$ \\
\hline Reducing costs & $10(55.6 \%)$ \\
\hline Increasing the quality of processes & $1(5.6 \%)$ \\
\hline Customer needs require continuous improvements & $3(16.7 \%)$ \\
\hline Greater control over work processes & $1(5.6 \%$ \\
\hline Increased productivity & $6(14.6 \%)$ \\
\hline \hline We do not have a risk management system in the warehouse & $1(16.7 \%)$ \\
\hline Reasons: & $3(50 \%)$ \\
\hline The financial investment required for implementing a system is too large & $2(33.3 \%)$ \\
\hline Warehousing is a less important process for our company & \\
\hline Lack of knowledge and experience for implementing a system & \\
\hline
\end{tabular}

Table 2 - The impact of the use of a risk management system on the use of storage and handling equipment and modern orderpicking solutions (results of the likelihood ratio test)

\begin{tabular}{|c|c|c|c|c|}
\hline & $\begin{array}{c}\text { We do not have a risk } \\
\text { management system } \\
(n=6) \\
f\end{array}$ & $\begin{array}{c}\text { We have a risk } \\
\text { management } \\
\text { system }(n=18) \\
f\end{array}$ & LR & $p$ \\
\hline \multicolumn{5}{|c|}{ Storage and handling equipment } \\
\hline Automated Guided Vehicles with a navigation system - AGV & $0(0 \%)$ & $1(5.6 \%)$ & 0.59 & 0.443 \\
\hline Automated Storage and Retrieval System - AS/RS & $0(0 \%)$ & $3(16.7 \%)$ & 1.86 & 0.172 \\
\hline \multicolumn{5}{|c|}{ Modern order-picking solutions } \\
\hline Radio Frequency Identification Technology - RFID & $1(16.7 \%)$ & $3(16.7 \%)$ & 0 & 1 \\
\hline Voice Picking Technology & $0(0 \%)$ & $0(0 \%)$ & - & - \\
\hline Light Picking Technology & $0(0 \%)$ & $0(0 \%)$ & - & - \\
\hline Barcode Technology & $3(50 \%)$ & $16(88.9 \%)$ & 3.69 & 0.055 \\
\hline Warehouse Management System - WMS & $1(16.7 \%)$ & $8(44.4 \%)$ & 1.62 & 0.203 \\
\hline
\end{tabular}


solutions (Radio Frequency Identification Technology - RFID, Warehouse Management System WMS), Voice Picking Technology (PbV), and Light Picking Technology $(\mathrm{PbL})$ were taken into account. Since RFID is a modern successor to Barcode technology, the latter was also analysed. A comparison between companies regarding the use of storage and handling equipment did not show statistically significant differences. Among the companies that use modern order-picking solutions, a higher level of trust can be detected only in the use of Barcode in companies that have a risk management system (88.9\%), compared to companies that do not have a risk management system $(50 \%)$, but the difference is only marginally statistically significant.

The results of the second hypothesis (H2) tested by independent sample t-test are shown in Table 4, preceded by the validity and reliability assessment of the measurement of the motivations for employing technology in the work process (Table 3). The validity of the measurement was verified by the factor analysis, despite the small number of companies involved in the survey. It is possible that the results of the analysis are less stable due to the small sample. Nevertheless, two factors were obtained, which are logical, contentwise. The former factor covers the statements relating to the reasons for the use of the technology that are related to employees, and the latter one covers the statements relating to warehousing. The KMO measure and theBartlett's test of specificity indicated that the reduction of variables in this case was justifiable $\left(\mathrm{KMO}=0.68 ; \chi^{2}=160.7 ; p<0.001\right)$. The two factors explain the $65.3 \%$ of the variability of the measured variables. The statement in grey has high weights on both factors and is therefore excluded from further analysis. The reliability of measurement of both measured factors is appropriate (Cronbach alpha coefficient is greater than 0.70 ). Two new variables (calculated composite score) were created as the average of the statements having high weights on each factor. These new variables were used as dependent variables when testing the second hypothesis, while the presence of a risk management system was included as an independent variable. The objective was to determine whether the companies that use risk management systems differ from companies that do not use the systems in their motivation for introducing modern warehouse technology.

Table 3 - Measurement validity and reliability of motivation of managers for employing technology in the work process of a company (results of factor analysis - factor weights and Cronbach $\alpha$ )

\begin{tabular}{||l|c|c||}
\hline & Employees & Warehousing \\
\hline \hline The company management wishes to... & & \\
\hline$\ldots$ increase control over warehouse employees & 0.51 & \\
\hline$\ldots$ increase the productivity of warehouse employees & 0.91 & 0.76 \\
\hline$\ldots$ improve warehouse processes & & \\
\hline$\ldots$ lower warehouse costs & 0.74 & \\
\hline$\ldots$ improve work time management & 0.81 & 0.46 \\
\hline$\ldots$ improve space planning at the exit of goods - dispatch & 0.65 & 0.93 \\
\hline$\ldots$ improve space planning at the entrance of goods - takeover & 0.67 & \\
\hline$\ldots$ improve the quality of warehouse data & & 0.81 \\
\hline$\ldots$ improve cooperation between employees & 0.86 & 0.85 \\
\hline Cronbach $\alpha$ & & \\
\hline
\end{tabular}

Note: Factor weights are obtained with principal factor axis method and after oblimin factor rotation.

Table 4-Comparison of groups of companies according to the system for risk management in the two main motivations for employment of the technology (results of t-test)

\begin{tabular}{|c|c|c|c|c|c|c|c|}
\hline & Risk management system & $n$ & M & $\mathrm{SD}$ & $t$ & $d f$ & $p$ \\
\hline \multirow{2}{*}{ Employees } & No & 6 & 4.17 & 0.71 & 2.13 & 22.00 & 0.045 \\
\hline & Yes & 18 & 3.44 & 0.72 & & & \\
\hline \multirow{2}{*}{ Warehousing } & No & 6 & 4.08 & 0.80 & 0.00 & 22 & 1 \\
\hline & Yes & 18 & 4.08 & 0.65 & & & \\
\hline
\end{tabular}


Table 5 - Frequent errors when using modern technology, according to the system for risk management (results of likelihood ratio test)

\begin{tabular}{||l|c|c|c|c||}
\hline \multicolumn{1}{|c|}{ Frequent errors when using } & $\begin{array}{c}\text { We do not have a } \\
\text { risk management } \\
\text { system } \\
f\end{array}$ & $\begin{array}{c}\text { We have a risk } \\
\text { management } \\
\text { system } \\
f\end{array}$ & LR & $p$ \\
\hline \hline Radio Frequency Identification Technology - RFID $(n=4)$ & $0(0 \%)$ & $0(0 \%)$ & - & - \\
\hline Barcode Technology $(n=19)$ & $1(33.3 \%)$ & $7(43.8 \%)$ & 0.12 & 0.735 \\
\hline Warehouse Management System - WMS $(n=9)$ & $0(0 \%)$ & $2(25 \%)$ & 0.54 & 0.464 \\
\hline
\end{tabular}

Table 4 shows the means and standard deviations for the two key motivations for the introduction of technology in each of the groups of companies. Companies that do not have a risk management system introduce technology in order to achieve better control over employees, compared to companies that have a risk management system $(p=0.045)$. There are no statistically significant differences between the groups of companies in the motivations for the introduction of technology related to warehousing.

The objective of the third hypothesis (H3) is to determine whether the presence of risk management has an effect on the frequency of errors in the use of modern warehouse technology. The results of the third hypothesis (H3) testing are shown in Table 5. None of the companies that use RFID $(n=4)$ often or very often report frequent errors when using RFID. A lower percentage (33.3\%) of companies that use Barcode technology $(n=19)$ and do not have a risk management system report frequent errors when using Barcode technology, compared with companies that have a risk management system (43.8\%). The difference in percentages is not statistically significant $(p=0.735)$. Of the nine companies that use WMS, none of those without a risk management system report frequent errors, while 2 companies that have a risk management system report frequent errors. The difference is not statistically significant $(p=0.464)$.

\section{DISCUSSION}

The companies in the analysed sample are aware of the importance of implementing a risk management system and thereby strengthening the company safety culture, as most are using adequate methodological approaches to ensure the reliability of warehousing. Thus, the basic condition is established for any errors in the work process to be dealt with strategically, with the goal of ensuring long-term stability of the company. In addition, the majority of the companies in the sample believe that using a risk management system in the warehouse increases the quality of the processes.

However, the analysis of the results of the first hypothesis suggests a different assessment of the effect of the use of risk management systems on the use of modern warehouse technology, as it did not show statistically significant differences. In $88.9 \%$ of companies that have a risk management system, a higher level of trust in the use of Barcode technology was detected, but the difference is only marginally statistically significant. In addition, Barcode technology does not meet the criteria for modern warehouse technology, as its technological successor is RFID. Indirectly, it can be inferred that the companies in the analysed sample use very little modern technological solutions. Voice Picking Technology $(\mathrm{PbV})$ and Light Picking Technology (PbL) are not used at all, which is surprising, given the fact that the companies are part of the international automotive industry - a generator of technological development in the world. The presence of risk management is not conditional upon an increased use of modern warehouse technology. Thus, the first hypothesis (H1) has been rejected.

The purpose of formulating the second hypothesis $(\mathrm{H} 2)$ was to determine whether the presence of risk management has an effect on the motivation of the company management to introduce modern storage technology. The results showed that they differ in terms of employee control. Companies that do not have a risk management system introduce the technology in order to achieve better control over the employees more often in a statistically significant measure, compared to companies that have a risk management system. The two groups of companies do not differ in terms of other motivations for the introduction of modern technology. Therefore, the second hypothesis (H2) has been partially 
confirmed. Nevertheless, the results indicate an important direction in the development of warehouse operations in the companies that have not implemented a risk management system. The latter are exclusively focused on having greater control over the warehouse employees, which can be problematic in the long term, as they are neglecting the fundamental competitive advantages of using modern technology, such as increased productivity and improved working conditions in the warehouse.

The objective of the third hypothesis (H3) was to determine whether the presence of risk management has an effect on the frequency of errors in the use of modern warehouse technology. An analysis of this hypothesis has not produced any statistically significant differences. Therefore, the third hypothesis (H3) has been rejected. The results have merely shown that a small percentage of companies using Barcode technology without a risk management system report frequent errors in the use of this technology.

The study was structured in order to look for a connection between the presence of risk management and the use of modern warehouse technology in practice, based on the existing gaps in theoretical knowledge. The hypotheses have been developed in order to examine the three factors in which risk management influences the use of modern warehouse technology: the type of modern technology used (H1), the motivation for use (H2) and the errors arising during use (H3). However, the analysis of the proposed hypotheses has not confirmed the expected connection. What became clear is that companies that do not have risk management in place believe that the implementation of modern technology only makes sense for the purpose of supervising their employees. Therefore, the presence of risk management systems in a warehouse does not affect the use of modern warehousing technology.

The central gap in the research was based on the assumption that the warehousing process in the Slovenian automotive industry is changing due to the introduction of RFID, $\mathrm{PbV}$ and $\mathrm{PbL}$ technologies. Warehouse operators interact more with information than with the physical movement of goods. The introduction of modern technology requires the presence of warehouse operators; therefore, it was essential in this process to look for a connection with the highest level of development of risk management - a culture of reporting errors. However, the main reason why most of the hypotheses have been rejected lies in the fact that companies in the Slovenian automotive industry use very little modern warehousing solutions. This is the reason for concern, considering the fact that this is an industry, in which high-tech processes are the norm. On the other hand, the results have revealed that companies are aware of the importance of risk management, since $75 \%$ of the companies in the sample have risk management in place. Despite a relatively small sample of companies, the results can be generalized to the Slovenian automotive industry, since all the Slovenian companies operating in the automotive industry - about fifty companies in total - were invited to participate. All the largest companies in the sector, which represent more than $50 \%$ of all the companies, have participated in the study. The sample of the participating companies represents 1.6 billion EUR of generated annual revenues, and the companies employ over 14,000 employees.

The result obtained mainly gives incentive to further research, from the point of view of determining the importance of warehousing in the Slovenian automotive industry, as strengthening the internal process within the company or managing warehousing through outsourcing. This research focus is all the more relevant, when comparing the report of the International Federation of Robotics [39], where Slovenia was first ranked among the countries with a large share of robots in the automotive industry, which is more than 1,000 robots per 10,000 employees. This is where a discrepancy is emerging between the level of automation in manufacturing and the level of warehouse automation in the Slovenian companies that are part of the international automotive industry.

Although the results of the research cannot be generalized to the entire automotive industry, the following conclusions can be extrapolated:

- modern technological solutions are underutilized by companies, which can have a negative impact on ensuring quality processes for customers in the automotive industry;

- the use of risk management systems only affects the use of Barcode technology, which is not considered modern technology in warehousing, as its technology successor is RFID;

- the completed study analyses and synthesizes current literature in the field of risk management in the warehousing process. In addition to the above, the paper highlights the theoretical connectedness between risk management and the use of modern technology, which is an important guideline for future empirical studies. 


\section{CONCLUSION}

The presented study shows the influence of the presence of risk management on the introduction of modern warehouse technology among the Slovenian companies that are part of the international automotive industry. The results are relevant for researchers as well as for warehouse managers, as they clearly indicate the future direction for research on the reliability of the warehousing process and the introduction of modern technological solutions. The practical aspect of the study also addresses the issues that are present in the warehousing system of the Slovenian companies within the international automotive industry, which are related to substandard technological equipment in warehouses, and to a discrepancy between the level of manufacturing automation and the level of warehousing automation. This has a significant effect on the results of the study, since the presence of risk management affects only the use of Barcode technology, which does not fall in the category of modern technological solutions in warehousing.

The study analyses a rather small sample of companies from the Slovenian automotive industry. However, since there are not many automotive companies in Slovenia, the results obtained represent an important guideline for future research in the field of ensuring the reliability of warehousing processes in the automotive industry in the Slovenian context. Nevertheless, the results cannot be generalized to the entire automotive industry, so it would be sensible to carry out a similar survey in other countries and compare the results.

ROBERT MUHA, Ph.D. ${ }^{1}$

E-mail: robert.muha@fpp.uni-lj.si

(Corresponding author)

SEBASTJAN ŠKERLIČ, Ph.D. ${ }^{1}$

E-mail: sebastjan.skerlic@fpp.uni-lj.si

VANJA ERČULJ, M.Sc. ${ }^{2}$

E-mail: vanja.erculj@fvv.uni-mb.si

${ }^{1}$ Univerza v Ljubljani

Fakulteta za pomorstvo in promet

${ }^{2}$ Univerza v Mariboru, Fakulteta za varnostne vede

Kotnikova ulica 8, 1000 Ljubljana, Slovenija

\section{POMEN UPRAVLJANJAS TVEGANJI PRI VPELJAVI SODOBNIH SKLADIŠČNIH TEHNOLOGIJ}

\section{POVZETEK}

Cilj študije je ugotoviti ali prisotnost upravljanja s tveganji (risk management) v skladišču zahteva implementacijo sodobne skladiščne tehnologije. Na podlagi analize literature je bilo mogoče opredeliti povezanost med prisotnostjo najvišjega nivoja risk managemanta in uporabo sodobne skladiščne tehnologije pri posameznih skladiščnih procesih. V ta namen je bila izdelana statistična analiza na vzorcu podjetij iz slovenske avtomobilske industrije, ki pa ni pokazala konkretne povezanosti med prisotnostjo risk managemanta z uporabo posamezne sodobne skladiščne tehnologije, motivacijo za njeno uporabo in napakah pri njeni uporabi. Rezultati raziskave zato izpostavljajo težave, $k i$ so prisotne $v$ skladiščnem sistemu slovenskih podjetij $v$ avtomobilski industriji, $k i$ se nanašajo na slabšo tehnološko opremljenost skladišč in diskrepanco med stopnjo avtomatizacije v proizvodnji in med stopnjo avtomatizacije skladiščenja. Rezultati so pomembni za slovensko avtomobilsko industrijo iz vidika uporabe sodobne tehnologije v visokotehnološkem okolju mednarodne avtomobilske industrije.

\section{KLJUČNE BESEDE}

skladiščenje; upravljanje s tveganji; zanesljivost skladiščenja; skladiščna tehnologija; metode; študija primera;

\section{REFERENCES}

[1] Jacyna-Gołda I, Lewczuk K. The method of estimating dependability of supply chain elements on the base of technical and organizational redundancy of process. $E k$ sploatacja i Niezawodnosc - Maintenance and Reliability. 2017;19(3): 382-392.

[2] Richards G. Warehouse management: a complete guide to improving efficiency and minimizing costs in the modern warehouse. London, Philadelphia: Kogan Page; 2011.

[3] Habazin J, Glasnović A, Bajor I. Order Picking Process in Warehouse: Case Study of Dairy Industry in Croatia. Promet - Traffic \& Transportation. 2017;29(1): 57-65.

[4] Škerlič S, Muha R. Reducing errors in the company's warehouse process. Transport problems. 2017;12(1): 8392.

[5] Richards, G. Warehouse Management: A Complete Guide to Improving Efficiency and Minimizing Costs in the Modern Warehouse. Second Edition. New Delhi: Kogan Page Ltd.; 2014.

[6] Tsarouchi P, Makris S, Chryssolouris G. Human-robot interaction review and challenges on task planning and programming. International Journal of Computer Integrated Manufacturing. 2016;29(8): 916-931.

[7] Merritt SM. Affective Processes in Human-Automation Interactions. Human Factors. 2011;53(4): 356-370.

[8] McBride SE, Rogers WA, Fisk AD. Understanding human management of automation errors. Theoretical Issues in Ergonomics Science. 2014;15(6): 545-577.

[9] Hancock PA. Automation: how much is too much? Ergonomics. 2014;57(3): 449-454.

[10] Everitt J, Fletcher S, Caird-Daley A. Task analysis of discrete and continuous skills: a dual methodology approach to human skills capture for automation. Theoretical Issues in Ergonomics Science. 2015;16(5): 513-532. 
[11] Reason J. Managing the risk of organizational accidents. Surrey: Ashgate cop.; 2011.

[12] Stapleton D, Hanna JB, Yagla S, Johnson J, Markussen D. Measuring Logistics Performance Using the Strategic Profit Model. International Journal of Logistics Management. 2002;13(1): 89-107.

[13] Škerlič S, Muha R. The importance of systems for controlling logistics costs in the supply chain : a case study from the Slovenian automotive industry. Promet - Traffic \&Transportation. 2016;28(3): 299-310.

[14] Mangan J, Lalwani C, Butcher T. Global logistics and supply chain management. Chichester: John Wiley \& Sons cop.; 2012.

[15] Dekker S. The field guide understanding human error Aldershot, U.K: Ashgate cop; 2006.

[16] Lam HY, Choy KL, Ho GTS, Cheng Stephen WY, Lee CKM. A knowledge-based logistics operations planning system for mitigating risk in warehouse order fulfillment. International Journal of Production Economics. 2015;170: 763-779.

[17] Tang CS. Perspectives in supply chain risk management. International Journal of Production Economics. 2006;103(2): 451-488.

[18] Manuj I, Mentzer JT. Global supply chain risk management strategies. International Journal of Physical Distribution \& Logistics Management. 2008;38(3): 192-223.

[19] Ho W, Zheng T, Yildiz H, Talluri S. Supply chain risk management: a literature review. International Journal of Production Research. 2015;53(16): 5031-5069.

[20] ISO, International Organization for Standardization. Available from: https://www.iso.org/iso-31000-riskmanagement.html [Accessed 15 ${ }^{\text {th }}$ December 2018].

[21] Randhawa SJ, Ahuja SI. An investigation into manufacturing performance achievements accrued by Indian manufacturing organization through strategic $5 \mathrm{~S}$ practices. International Journal of Productivity and Performance Management. 2018;67(4): 754-787.

[22] Ohno T. Workplace Management. Cambridge, MA: Productivity Press; 1988.

[23] Health and Safety Executive. Warehousing and storage: A guide to health and safety. Second edition, 2007. Available from: http://www.hse.gov.uk/logistics/ warehousing.htm [Accessed 29 ${ }^{\text {th }}$ May 2019].

[24] Yan R, Jackson LM, Dunnett SJ. Automated guided vehicle mission reliability modelling using a combined fault tree and Petri net approach. The International Journal of Advanced Manufacturing Technology. 2017;92(5-8): 1825-1837.

[25] Choy KL, Sheng N, Lam HY, Lai Ivan KW, Chow KH, Ho GTS. Assess the effects of different operations policies on warehousing reliability. International Journal of Production Research. 2014;52(3): 662-678.

[26] Ryu H, Kim N, Lee J, Shin D. An Affordance-Based
Model of Human Action Selection in a Human-Machine Interaction System with Cognitive Interpretations. International Journal of Human-Computer Interaction. 2016;32(5): 402-414.

[27] Cochran DS, Arinez JF, Collins MT, Bi Z. Modelling of human-machine interaction in equipment design of manufacturing cells. Enterprise Information Systems. 2017;11(7): 969-987.

[28] Caputo AC, Pelagagge PM, Salini P. Modelling human errors and quality issues in kitting processes for assembly lines feeding. Computers \& Industrial Engineering. 2017;111: 492-506.

[29] Rajković M, Zrnić N, Kosanić N, Borovinšek M, Lerher T. A multi-objective optimization model for minimizing investment expenses, cycle times and $\mathrm{CO} 2$ footprint of an automated storage and retrieval systems. Transport. 2019;34(2): 275-286.

[30] Janilionis V, Bazaras Ž. The design and investigation of two storage/retrieval mechanisms of the cylindrical automated storage and retrieval system. Transport. 2013;28(4): 352-360.

[31] Ricrads G. Warehouse Management: A Complete Guide to Improving Efficiency and Minimizing Costs in the Modern Warehouse. Third Edition. New Delhi: Kogan Page Ltd.; 2017.

[32] Stock, JR, Lambert DM. Strategic logistics management. $4^{\text {th }}$ ed. Boston, etc.: McGraw-Hill Irwin; 2001.

[33] Blanchard D. Supply chain management: Best practices. Hoboken, New Jersey: John Wiley \& Sons, cop; 2010.

[34] Son DW, Chang YS, Choi HC, Kim WR, Higuera AG. A study of building a new warehouse control system architecture. International Journal of Advanced Logistics. 2015;4(3): 145-158.

[35] Dujmešić N, Bajor I, Rožić T. Warehouse Processes Improvement by Pick by Voice Technology. Tehnički vjesnik - Technical Gazette. 2018;25(4): 1227-1233.

[36] Marchet G, Melacini M, Perotti S. Investigating order picking system adoption: a case-study-based approach. International Journal of Logistics Research and Applications. 2015;18(1): 82-98.

[37] Hollnagel E. Cognitive reliability and error analysis method. Oxford: Elsevier Science Ltd; 1998.

[38] GIZ ACS, Slovenski avtomobilski grozd. 2019. Available from: http://www.acs-giz.si/o-acs [Accessed $17^{\text {th }}$ January 2019].

[39] IFR, The International Federation of Robotics. Global industrial robot sales doubled over the past five years. 2018. Available from: https://ifr.org/ifr-press-releases/ news/global-industrial-robot-sales-doubled-over-thepast-five-years [Accessed 22 ${ }^{\text {nd }}$ May 2019]. 